\title{
FRUIT AND SEED MORFOMETRY, SEED GERMINATION AND SEEDLING VIGOR of Parkia gigantocarpa
}

\author{
Hellen Síglia Demétrio Barros ${ }^{1}$, Eniel David $\mathrm{Cruz}^{2}$, Adriano Gonçalves Pereira ${ }^{3}$, Edvaldo Aparecido \\ Amaral da Silva ${ }^{4}$ \\ ${ }^{1}$ São Paulo State University, Graduate Program in Agronomy (Agriculture), Botucatu, São Paulo, Brazil - \\ hellen_siglia@yahoo.com.br \\ 22Embrapa Oriental Amazonia, Laboratory of Ecophysiology, Belém, Pará, Brazil - eniel.cruz@embrapa.br \\ ${ }^{3}$ Emilio Goeldi Museum of the State of Pará, Graduate Program in Biological Sciences (Tropical Botany), Belém, Pará, Brazil - \\ adripere07@gmail.com \\ ${ }^{1}$ São Paulo State University, Department of Plant Production and Breeding, Botucatu, São Paulo, Brazil - \\ amaraldasilva@fca.unesp.br
}

Received for publication: 11/12/2017 - Accepted for publication: 24/01/2019

\begin{abstract}
Resumo
Aspectos morfométricos de frutos e sementes, germinação e vigor de plântulas de Parkia gigantocarpa Ducke. $\mathrm{O}$ objetivo do trabalho foi caracterizar frutos e sementes de Parkia gigantocarpa e avaliar a germinação e o vigor das plântulas oriundas de quinze plantas matrizes. Foram mensurados a massa fresca, o comprimento, a largura e a espessura dos frutos e sementes. $\mathrm{O}$ teste de germinação foi realizado em substrato areia, com quatro repetições de 25 sementes por tratamento (plantas matrizes). Durante o teste foram avaliados o número de dias para o início da emergência, a porcentagem de emergência, o índice de velocidade de emergência, a porcentagem germinação e a massa seca das plântulas. Os frutos apresentaram médias de massa fresca, comprimento, largura e espessura de $115,0 \mathrm{~g} ; 621,3 \mathrm{~mm} ; 60,8 \mathrm{~mm}$ e $9,8 \mathrm{~mm}$, respectivamente. As sementes apresentaram médias de $1,1 \mathrm{~g} ; 22,8 \mathrm{~mm} ; 11,2 \mathrm{~mm}$ e 7,0 mm, respectivamente para as mesmas características anteriores. A emergência foi rápida e uniforme, iniciando a partir do quinto ao sexto dia após a semeadura, atingindo germinação de $91 \%$ para a matriz HB9, não se diferenciando das matrizes HB2, HB3 e HB6. As plântulas oriundas das matrizes HB2, HB3, HB6 e HB9 foram mais vigorosas, devido ao maior acumulo de massa seca. A partir dos resultados obtidos conclui-se que, mesmo pertencendo a mesma espécie, as sementes provenientes de diferentes plantas matrizes de $P$. gigantocarpa apresentam variabilidade nas características biométricas dos frutos e sementes. A partir da coleta de sementes de diferentes plantas matrizes, observa-se diferenças na capacidade germinativa e no vigor das plântulas.

Palavras-chave: fava-barriguda; árvores matrizes; sementes florestais; biometria de sementes.
\end{abstract}

\begin{abstract}
The objectives of this work were to characterize fruits and seeds and evaluate seed germination and seedling vigor from fifteen parent plants of Parkia gigantocarpa Ducke. The fresh weight, length, width, and thickness of fruits and seeds were determined. The germination was tested in a sand substrate, with four replications of 25 seeds per treatment (parent plants). The number of days for emergence, emergence percentage, emergence speed index, germination percentage, and seedling dry weight were evaluated. The fruits presented means for fresh weight, length, width, and thickness of $115.0 \mathrm{~g} ; 621.3 \mathrm{~mm} ; 60.8 \mathrm{~mm}$, and $9.8 \mathrm{~mm}$, respectively. The seeds presented means for fresh weight, length, width, and thickness of $1.1 \mathrm{~g}, 22.8 \mathrm{~mm}, 11.2 \mathrm{~mm}$, and $7.0 \mathrm{~mm}$, respectively. The emergence was fast and uniform, which occurred from the fifth to the sixth day after seeding, reaching 91\% germination for the parent HB9, but not differing from the parents HB2, HB3, and HB6. The seedlings from the parents HB2, HB3, HB6, and HB9 were more vigorous due to their higher dry matter accumulation. The results found showed that, even belonging to the same species, $P$. gigantocarpa seeds from different parent plants present variability in biometric characteristics of fruits and seeds. The seed collected from different parent plants showed differences in germination capacity and seedling vigor.

Keywords: fava-barriguda; parent trees; forest seeds; seed biometry.
\end{abstract}

\section{INTRODUCTION}

The species Parkia gigantocarpa Ducke is known in Brazil as fava-barriguda; it belongs to the Fabaceae family, and adult individuals can reach 60-m height and 1.50-m diameter at breast height (PAULA; ALVES, 1997). This tree is found in inland forests and high floodplains, occurring in Brazil in the states of Rondônia, Pará, Amapá, and Amazonas (EMBRAPA, 2004).

This tree can be used for landscaping in urban parks and streets, and its wood can be used for furniture and constructions (CARVALHO, 2010). It is also important for recovering of degraded areas because of its rapid

FLORESTA, Curitiba, PR, v. 50, n. 1, p. 877 - 886, jan/mar 2020.

Barros, H. S. D. et.al.

ISSN eletrônico 1982-4688

DOI: $10.5380 /$ rf.v50 i1.56855 
growth and high survival rate in clearing areas, which is important for the establishment of species in these environments (GOMES et al., 2010).

However, due to the increasing wood exploitation and deforesting for agriculture, several native tree species in the Amazonia that have potential for ornamental, wood, and food uses are at risk of extinction, with consequent decreasing in genetic variability.

Studies on biometry of fruits and seeds are important for botanical identification of species. This identification is made by evaluations through external and internal characteristics of seeds due to the little effect of the environment in the phenotype, forming safe criteria for these identifications (CRUZ et al., 2001; FONTENELLE et al., 2007; SILVA; MORO, 2008).

Biometry studies can also detect genetic variability in populations of the same species (GUSMÃO et al., 2006) and, combined with germination tests, allow the evaluation of seedling vigor from parents with the best potential for further studies on plant breeding for the species. Thus, seed classification by size or weight is a strategy that can be adopted to uniform seedling emergence and obtain seedlings with similar size or higher vigor (CARVALHO; NAKAGAWA, 2012).

However, despite the potentials of $P$. gigantocarpa, little is known about the biometric characteristics of its fruits and seeds. The hypothesis of this work was that this species can be identified from its biometric characteristics of fruits and seeds. Thus, the objectives of this work were to characterize the morphometry of fruits and seeds and evaluate seed germination and seedling vigor from fifteen parent plants of Parkia gigantocarpa Ducke.

\section{MATERIAL AND METHODS}

The maturation index used to determine the time for collection of $P$. gigantocarpa fruits was the change of pods color-from green to a dark-brown color, almost black. Ripe fruits were harvested from fifteen marked trees that were at a minimum distance of 91 meters between them, in native forests at the Rio Capim Farm and São Romualdo Farm, in Paragominas, Pará, Brazil (0257'56"S, 47040’21"W), in 2010. The fruits were manually harvested by direct collection from the tree, by climbing the tree using proper shoes and a safety belt. The extremities of branches with fruits were cut using a tree trimmer; then, the fruits were placed in raffia bags that were identified by tree.

The fruits were then taken to the Laboratory of Ecophysiology and Plant Propagation of the Embrapa Oriental Amazonia in Belém, PA, Brazil, where the biometry of fruits and seeds was evaluated. Subsequently, the seeds were taken to the Laboratory of Seed Analysis of the Faculty of Agronomic Sciences of the São Paulo State University, in Botucatu, SP, Brazil, for evaluations of germination and initial development of seedlings (vigor).

\section{Biometry of fruits and seeds}

The biometric characteristics of fruits and seeds were evaluated in 50 fruits randomly chosen from each tree (totaling 750 fruits). The fruit length, width, and thickness were evaluated using a ruler and a digital caliper. The length of fruits without peduncle was measured from the base to the apex; and the width and thickness were measured in the medium part of the fruits. The fruit fresh matter was determined in a digital precision balance $(0.001 \mathrm{~g})$.

The fruits were opened with prune shears to extract their seeds, which were washed with liquid detergent to eliminate the mucilage in the external part and, then, they were shade dried on sieves. The characteristics evaluated were: number of seeds per fruit, number of intact seeds (without damages caused by insects or malformation), number of seeds damaged by insects, and number of empty seeds (not fecundated). The length, width, and thickness of intact seeds $(11,077$ seeds) were evaluated using a digital caliper.

\section{Evaluation of physical characteristics of seeds}

The seed water content was determined individually for each parent tree (treatments): HB1, HB2, HB3, HB4, HB5, HB6, HB7, HB8, HB9, HB10, HB11, HB12, HB13, HB14, and HB15. Ten replications of one seed per replication were done, applying the oven method at $103 \pm 2{ }^{\circ} \mathrm{C}$ for 17 hours (BRASIL, 2009).

The 100-seed weight was determined for each parent, using eight replications of 100 seeds randomly taken from each batch, as described in Brasil (2009). The data was uniformized regarding seed weight: water content was corrected to $6.8 \%$ by monitoring the drying process and, subsequently, using the equation described by Cromarty et al. (1985). 


\section{Germination evaluation}

Germination tests were conducted in biochemical oxygen demand (BOD) germination chambers, at temperature of $30^{\circ} \mathrm{C}$ and photoperiod of 12 hours, for 12 days.

The seeds were disinfested with $2 \%$ sodium hypochlorite solution during 3 minutes, washed with distilled water for 1 minute, and placed on a paper towel to dry for 15 minutes. Then, the seeds were scarified with electric emery, focusing on the median and lateral regions, for overcoming of dormancy.

The germination tests were done for each parent plant, adopting four replications of 25 seeds. The seeding was done using sand as substrate in plastic pots $(16 \times 13 \times 13 \mathrm{~cm})$; the sand was previously sterilized in an oven at $105^{\circ} \mathrm{C}$ for 24 hours.

The substrates were irrigated according to the field capacity and, after seeding, they were irrigated every three days.

The following parameters were evaluated daily during the germination tests: number of days for seedling emergence; seedling emergence percentage, when the hypocotyls were at least $0.5 \mathrm{~cm}$ above the substrate surface; and emergence speed index (ESI), according to the equation described by Maguire (1962).

After the tests, the percentages of germination (normal seedlings), abnormal seeds, and dead seeds were evaluated according to Brasil (2009).

\section{Seedling dry weight}

The growth of normal seedlings was determined by the dry weights of shoot (hypocotyl and epicotyl), leaves, and main root, after they were placed in paper bags and dried in a forced-air circulation oven at $65^{\circ} \mathrm{C}$ for 48 hours. The results were divided by the total number of seeds (25 seeds), according to Nakagawa (1999).

\section{Statistical analysis}

The biometric data of fruits and seeds was analyzed using the frequency distribution. All data were subjected to correlation analysis, calculating the Person's coefficient of linear correlation (r) and testing its significance by the $t$ test at 5\% probability (ZAR, 1999) through descriptive statistics, using the MS Excel 2010 program.

The germination was tested using a randomized block design, consisting of 15 treatments (parent plants HB1 to HB15) and four replications of 25 seeds. The data were subjected to variance homogeneity by the Levene test and showed homogeneity. Subsequently, the means were compared by the Tukey's test at 5\% probability, using the Sisvar 5.3 program.

\section{RESULTS}

The fruits of $P$. gigantocarpa are pods, whose fresh weight, length, width, and thickness varied from 45.4 to $183.1 \mathrm{~g}, 275.0$ to $905.0 \mathrm{~mm}, 50.8$ to $93.0 \mathrm{~mm}$, and 6.6 to $11.9 \mathrm{~mm}$, respectively. The fruits presented means of fresh weight of $115.0 \mathrm{~g}$, length of $621.3 \mathrm{~mm}$, width $60.8 \mathrm{~mm}$, and thickness of $9.8 \mathrm{~mm}$. The amount of seeds per fruit varied from 13 to 38 ; and the means of intact seeds, seeds damaged by insects, and empty seeds per fruit were 47.4, 6.7, and 45.9, respectively (Table 1).

The biometrics of seeds varied from 0.7 to $1.6 \mathrm{~g}$ for fresh weight; 19.9 to $27.0 \mathrm{~mm}$ for length; 8.8 to 13.5 $\mathrm{mm}$ for width; and 4.8 to $8.6 \mathrm{~mm}$ for thickness. The means of seed fresh weight, length, width, and thickness were $1.1 \mathrm{~g}, 22.8 \mathrm{~mm}, 11.2 \mathrm{~mm}$, and $7.0 \mathrm{~mm}$, respectively.

Table 1 shows that the fruits presented low coefficient of variation for length $(13.2 \%)$, width $(7.8 \%)$, thickness (6.4\%), and number of seeds per fruit (13.2\%); medium coefficient of variation for fruit weight (20.3\%) and for number of intact seeds (46.6\%); and high coefficient of variation for number of seeds damaged by insects $(63.3 \%)$ and number of empty seeds per fruit (105.0\%).

The seeds presented lower variation in weight and size than fruits, considering that the coefficient of variation and of standard deviation of these characteristics were lower.

FLORESTA, Curitiba, PR, v. 50, n. 1, p. 877 - 886, jan/mar 2020. 
Table 1. Minimum, maximum, and mean results, standard deviation, and coefficient of variation (CV) of biometry parameters of fruits and seeds of Parkia gigantocarpa.

Tabela 1. Valores mínimos, máximos, médios, desvio padrão e coeficiente de variação (CV) da biometria dos frutos e sementes de Parkia gigantocarpa.

\begin{tabular}{lcccc}
\hline Characteristic & Minimum & Maximum & Mean & CV (\%) \\
\hline Fruit weight (g) & 45.4 & 183.1 & $115.0( \pm 23.1)$ & 20.3 \\
Fruit length (mm) & 275.0 & 905.0 & $621.3( \pm 82.1)$ & 13.2 \\
Fruit width (mm) & 50.8 & 93.0 & $60.8( \pm 4.71)$ & 7.8 \\
Fruit thickness (mm) & 6.6 & 11.9 & $9.8( \pm 0.63)$ & 6.4 \\
Seeds per fruit (n) & 13 & 38 & $29.9( \pm 3.94)$ & 13.2 \\
Intact seeds (\%) & 0 & 100 & $47.4( \pm 22.04)$ & 46.5 \\
Seeds damaged by insects (\%) & 0 & 100 & $6.7( \pm 7.01)$ & 63.3 \\
Empty seeds (\%) & 0 & 100 & $45.9( \pm 20.93)$ & 105.0 \\
Seed weight (g) & 0.7 & 1.6 & $1.1( \pm 0.14)$ & 12.0 \\
Seed length (mm) & 19.9 & 27.0 & $22.8( \pm 1.37)$ & 6.0 \\
Seed width (mm) & 8.8 & 13.5 & $11.2( \pm 0.82)$ & 7.3 \\
Seed thickness (mm) & 4.8 & 8.6 & $7.0( \pm 0.59)$ & 8.5 \\
\hline
\end{tabular}

The biometry of fruits showed higher frequencies for the classes of weight between 87.0 and $129.0 \mathrm{~g}$ $(68.2 \%)$ (Figure 1A), length between 590.0 and $653.0 \mathrm{~mm}(35.1 \%)$ (Figure 1B), width between 61.0 and $66.0 \mathrm{~mm}$ $(34.1 \%)$ (Figure 1C), and thickness between 10.0 and $11.0 \mathrm{~mm}(52.7 \%)$ (Figure 1D).
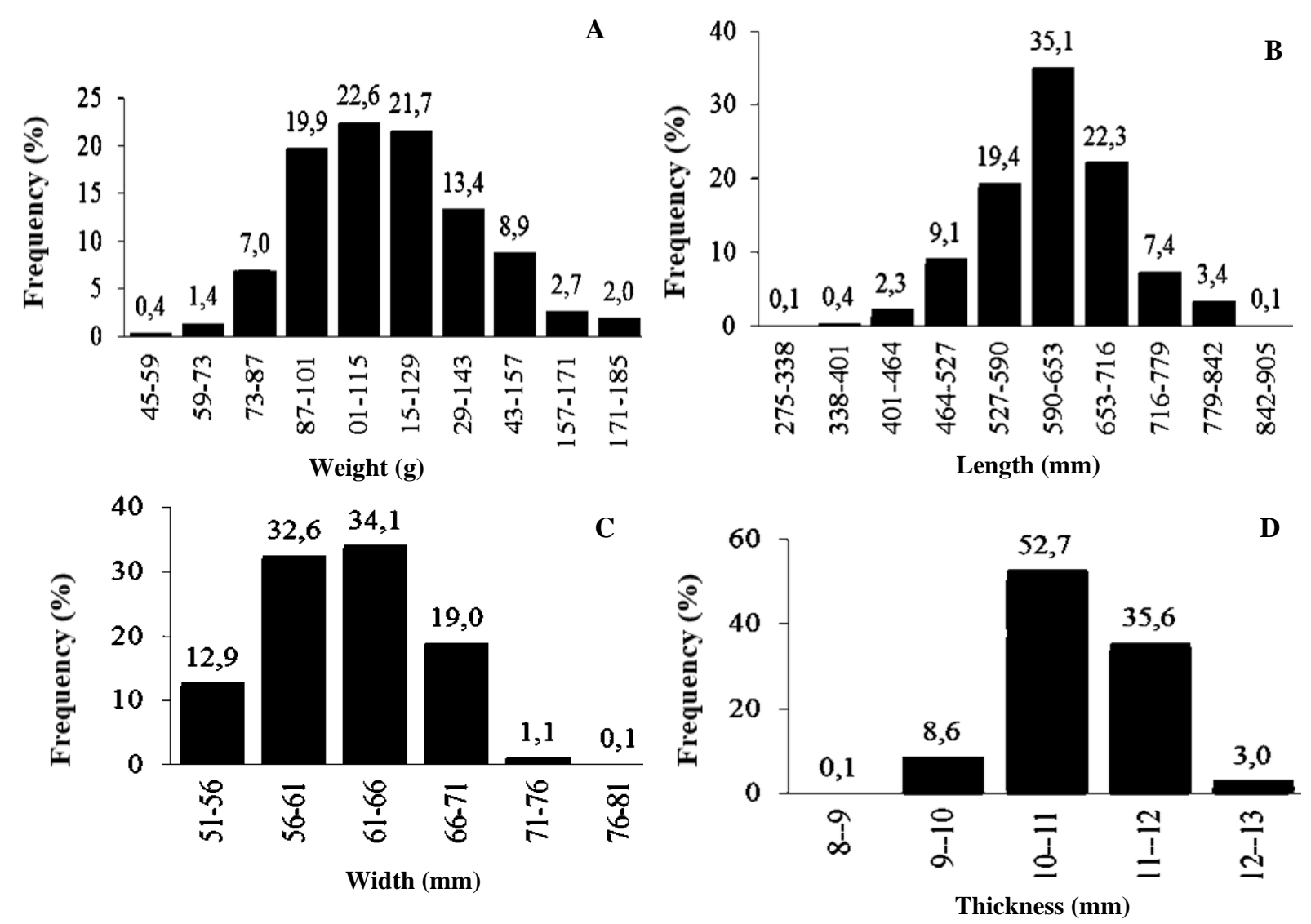

Figure 1. Distribution of the relative frequencies (Fr) of weight (A), length (B), width (C), and thickness (D) of fruits of Parkia gigantocarpa.

Figura 1. Distribuição das frequências relativas (Fr) da massa (A), comprimento (B), largura (C) e espessura (D) dos frutos de Parkia gigantocarpa. 
The biometry of seeds showed higher frequencies for the classes of weight between 1.1 and $1.3 \mathrm{~g}(52.8 \%)$ (Figure 2A), length between 20.9 and $24.9 \mathrm{~mm}$ (70.3\%) (Figure 2B), width between 10.8 and $11.8 \mathrm{~mm}(43.9 \%)$ (Figure 2C), and thickness between 6.8 and $7.8 \mathrm{~mm}$ (64\%) (Figure 2D).
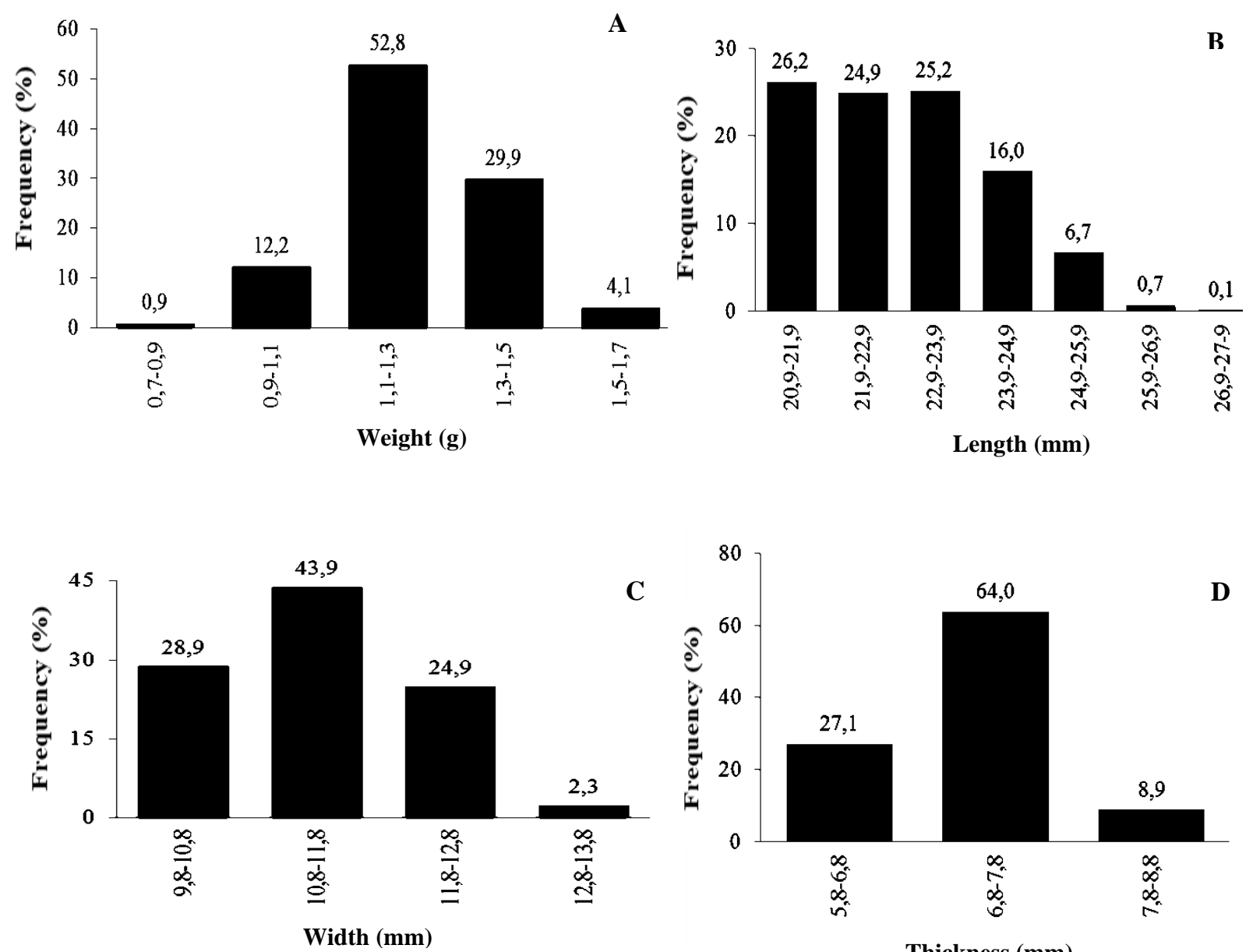

Thickness (mm)

Figure 1. Distribution of the relative frequencies (Fr) of weight (A), length (B), width (C), and thickness (D) of seeds of Parkia gigantocarpa.

Figura 2. Distribuição das frequências relativas (Fr) da massa (A), comprimento (B), largura (C) e espessura (D) das sementes de Parkia gigantocarpa.

The results of correlation of biometric data of fruits and seeds are presented in Table 2. Positive and significant correlations were found between fruits with higher weight and length in relation to the total number of seeds per fruit and to seed weight. However, negative and significant correlations were found for the number of empty seeds per fruit, fruit weight, and fruit length. 
Table 2. Coefficient of correlation ( $r$ ) between fruit weight (FWe), fruit length (FL), fruit width (FWi), fruit thickness (FT), total number of seeds per fruit (TNS), number of intact seeds per fruit (NIS), number of empty seeds per fruit (NES), number of damaged seeds per fruit (NDS), seed weight (SWe), seed length (SL), seed width (SWi), and seed thickness (ST) of a population of fifteen parent plants of Parkia gigantocarpa.

Tabela 2. Coeficiente de correlação (r) entre massa do fruto (MF), comprimento do fruto (CF), largura do fruto (LF), espessura do fruto (EF), número total de sementes por fruto (NTS), número de sementes intactas por fruto (NSI), número de sementes vazias por fruto (NSV), número de sementes danificadas por fruto (NSD), massa da semente (MS), comprimento da semente (CS), largura da semente (LS) e espessura da semente (ES) de uma população de quinze plantas matrizes de Parkia gigantocarpa.

\begin{tabular}{|c|c|c|c|c|c|c|c|c|c|c|c|}
\hline & FL & FWi & FT & TNS & NIS & NES & NDS & SWe & SL & SWi & ST \\
\hline FWe & $0.58^{*}$ & $0.27 *$ & $0.02^{\mathrm{NS}}$ & $0.42 *$ & $0.32 *$ & $-0.14 *$ & $-0.06^{\mathrm{NS}}$ & $0.36^{*}$ & $0.05^{\mathrm{NS}}$ & $0.25^{*}$ & $0.22 *$ \\
\hline FL & & $0.17 *$ & $0.03^{\mathrm{NS}}$ & $0.43 *$ & $0.17 *$ & $-0.10^{*}$ & $0.09 *$ & $0.14^{*}$ & $-0.08^{*}$ & $0.17 *$ & $0.04^{\mathrm{NS}}$ \\
\hline FWi & & & $0.01^{\mathrm{NS}}$ & $0.02^{\mathrm{NS}}$ & $-0.35^{*}$ & $0.08^{*}$ & $0.35^{*}$ & $0.08^{*}$ & $0.03^{\mathrm{NS}}$ & $-0.09 *$ & $-0.09 *$ \\
\hline FT & & & & $0.00^{\mathrm{NS}}$ & $-0.02^{\mathrm{NS}}$ & $-0.06^{\mathrm{NS}}$ & $0.04^{\mathrm{NS}}$ & $0.06^{\mathrm{NS}}$ & $0.03^{\mathrm{NS}}$ & $0.02^{\mathrm{NS}}$ & $0.06^{\mathrm{NS}}$ \\
\hline TNS & & & & & $0.21^{*}$ & $0.05^{\mathrm{NS}}$ & $0.31 *$ & $-0.11^{*}$ & $-0.16^{*}$ & $-0.15^{*}$ & $-0.11 *$ \\
\hline NIS & & & & & & $-0.31 *$ & $-0.81 *$ & $0.19 *$ & $0.23^{*}$ & $0.34 *$ & $0.17 *$ \\
\hline NES & & & & & & & $0.02^{\mathrm{NS}}$ & $-0.10^{*}$ & $0.00^{\mathrm{NS}}$ & $-0.08^{*}$ & $-0.09 *$ \\
\hline NDS & & & & & & & & $-0.22 *$ & $-0.32 *$ & $-0.41 *$ & $-0.21 *$ \\
\hline SWe & & & & & & & & & $0.81^{*}$ & $0.83^{*}$ & $0.90^{*}$ \\
\hline SL & & & & & & & & & & $0.83^{*}$ & $0.79^{*}$ \\
\hline SWi & & & & & & & & & & & $0.79 *$ \\
\hline
\end{tabular}

${ }^{\text {NS }}$ Not significant; *Significant at $5 \%$ probability by the $t$ test.

\section{Physical characteristics and germination of seeds, and seedling dry weight}

All variables evaluated presented significant differences from the parent plants, except for number of days for seedling emergence, which occurred from the fifth to the sixth day after seeding (Table 3). This can be attributed to the efficacy of the mechanical scarification of the seeds used, which resulted in a rapid and uniform germination. The initial seed water contents varied from $6.8 \%$ to $11.3 \%$, which was important to assess the seed performance during germination.

Seeds from the parent plant HB7 presented higher water content (11.3\%) and lower germination percentage $(43 \%)$.

Seedling emergence was above $80 \%$ for the treatments HB1, HB2, HB3, HB4, HB6, HB9, and HB12. However, the seeds of the parent plants HB3 and HB9, presented higher vigor when considering their emergence speed index, which were 3.80 and 3.56 , respectively.

The results of the germination test showed high variation, with better percentages for the parent plant HB9, which had 91\% germination, but not significantly differing from HB2, HB3, and HB6.

The results of emergence showed that the seedlings that did not emerge presented one or more abnormalities: they were classified as abnormal seedlings, or as dead seeds because they rotted. 
Table 3. Means for 100-seed weight (100SW) corrected for water content of $6.8 \%$, water content (U), emergence (E), emergence speed index (ESI), germination (G), abnormal seedlings (AS), and dead seeds (DS) from plant parents of Parkia gigantocarpa (treatments BH1 to HB15).

Tabela 3. Tratamento (planta matriz), massa de 100 sementes (MS) corrigido para o teor de água de 6,8\%, teor de água (U), emergência (E), índice de velocidade de emergência (IVE), germinação (G), plântulas anormais (PA) e sementes mortas (SM) em matrizes de Parkia gigantocarpa.

\begin{tabular}{cccccccc}
\hline Treatment & 100SW $(\mathbf{g})$ & U $(\%)$ & E $(\%)$ & ESI & G $(\%)$ & AS $(\%)$ & DS $(\%)$ \\
\hline HB1 & $87.2 \mathrm{~h}$ & $10.2 \mathrm{abcd}$ & $85 \mathrm{ab}$ & $2.95 \mathrm{~cd}$ & $63 \mathrm{de}$ & $27 \mathrm{~b}$ & $10 \mathrm{~cd}$ \\
HB2 & $118.7 \mathrm{~b}$ & $11.1 \mathrm{ab}$ & $93 \mathrm{a}$ & $2.96 \mathrm{bcd}$ & $75 \mathrm{abcd}$ & $21 \mathrm{bcd}$ & $4 \mathrm{~d}$ \\
HB3 & $106.8 \mathrm{fg}$ & $7.6 \mathrm{ef}$ & $98 \mathrm{a}$ & $3.80 \mathrm{a}$ & $86 \mathrm{ab}$ & $13 \mathrm{~cd}$ & $1 \mathrm{~d}$ \\
HB4 & $106.7 \mathrm{~g}$ & $9.6 \mathrm{bcd}$ & $83 \mathrm{ab}$ & $2.96 \mathrm{~cd}$ & $66 \mathrm{de}$ & $21 \mathrm{bcd}$ & $13 \mathrm{~cd}$ \\
HB5 & $111.1 \mathrm{def}$ & $10.5 \mathrm{abc}$ & $65 \mathrm{de}$ & $2.16 \mathrm{efg}$ & $40 \mathrm{~g}$ & $42 \mathrm{a}$ & $18 \mathrm{c}$ \\
HB6 & $131.2 \mathrm{a}$ & $7.5 \mathrm{ef}$ & $82 \mathrm{abc}$ & $3.05 \mathrm{bc}$ & $78 \mathrm{abc}$ & $12 \mathrm{~d}$ & $10 \mathrm{~cd}$ \\
HB7 & $109.8 \mathrm{defg}$ & $11.3 \mathrm{a}$ & $51 \mathrm{ef}$ & $2.02 \mathrm{fg}$ & $43 \mathrm{fg}$ & $16 \mathrm{bcd}$ & $41 \mathrm{~b}$ \\
HB8 & $117.7 \mathrm{~b}$ & $11.0 \mathrm{ab}$ & $44 \mathrm{fg}$ & $1.66 \mathrm{gh}$ & $36 \mathrm{~g}$ & $20 \mathrm{bcd}$ & $44 \mathrm{ab}$ \\
HB9 & $113.3 \mathrm{~cd}$ & $10.5 \mathrm{abc}$ & $98 \mathrm{a}$ & $3.56 \mathrm{ab}$ & $91 \mathrm{a}$ & $9 \mathrm{~d}$ & $0 \mathrm{~d}$ \\
HB10 & $108.2 \mathrm{efg}$ & $10.1 \mathrm{abcd}$ & $74 \mathrm{bcd}$ & $2.71 \mathrm{cde}$ & $61 \mathrm{de}$ & $26 \mathrm{bc}$ & $13 \mathrm{~cd}$ \\
HB11 & $107.6 \mathrm{efg}$ & $9.3 \mathrm{~cd}$ & $34 \mathrm{~g}$ & $1.13 \mathrm{~h}$ & $28 \mathrm{~g}$ & $16 \mathrm{bcd}$ & $56 \mathrm{a}$ \\
HB12 & $109.3 \mathrm{defg}$ & $6.8 \mathrm{f}$ & $83 \mathrm{ab}$ & $2.68 \mathrm{cde}$ & $73 \mathrm{cde}$ & $17 \mathrm{bcd}$ & $10 \mathrm{~cd}$ \\
HB13 & $117.3 \mathrm{bc}$ & $9.9 \mathrm{abcd}$ & $45 \mathrm{fg}$ & $1.59 \mathrm{gh}$ & $37 \mathrm{~g}$ & $16 \mathrm{bcd}$ & $47 \mathrm{ab}$ \\
HB14 & $110.9 \mathrm{defg}$ & $8.7 \mathrm{de}$ & $66 \mathrm{cde}$ & $2.17 \mathrm{efg}$ & $58 \mathrm{ef}$ & $22 \mathrm{bcd}$ & $20 \mathrm{c}$ \\
HB15 & $111.8 \mathrm{de}$ & $6.8 \mathrm{f}$ & $74 \mathrm{bcd}$ & $2.39 \mathrm{def}$ & $66 \mathrm{de}$ & $15 \mathrm{bcd}$ & $19 \mathrm{c}$ \\
\hline
\end{tabular}

Means followed by the same letter in the column are not different by the Tukey's test $(\mathrm{P}>0.05)$.

Significant differences between the treatments were found for seedling dry weight. Table 4 shows that seedlings from seeds of the plant parent HB9 presented high root, shoot, and leaf dry weights $(43.2,177.7$, and $106.5 \mathrm{~g}$ seedling ${ }^{-1}$, respectively), those from seeds of HB6 presented high root and leaf dry weights (49.2 and 121.0 $\mathrm{g}$ seedling ${ }^{-1}$, respectively), those from seeds of HB2 had high shoot weight (221.2 $\left.\mathrm{g} \mathrm{seedling}^{-1}\right)$, and those from seeds of HB3 presented high leaf dry weight $\left(135.2 \mathrm{~g}\right.$ seedling $\left.{ }^{-1}\right)$, i.e., resulted in vigorous seedlings. 
Table 4. Root dry weight (RDW), shoot dry weight (SDW), and leaf dry weight (LDW) of seedlings from seeds of parent plants of Parkia gigantocarpa (treatments HB1 to HB15).

Tabela 4. Tratamento (planta matriz), massa seca da raiz (MSR), massa seca da parte aérea (MSPA) e massa seca das folhas (MSF) das plântulas de Parkia gigantocarpa.

\begin{tabular}{lccc}
\hline Treatment & RDW $\left(\right.$ g seedling $\left.^{-1}\right)$ & SDW $\left(\mathbf{g ~ s e e d l i n g ~}^{-1}\right)$ & LDW $\left(\mathbf{g ~ s e e d l i n g}^{-1}\right)$ \\
\hline HB1 & $16.0 \mathrm{efgh}$ & $68.5 \mathrm{gh}$ & $56.0 \mathrm{ef}$ \\
HB2 & $24.8 \mathrm{cdefg}$ & $221.2 \mathrm{a}$ & $73.2 \mathrm{de}$ \\
HB3 & $34.5 \mathrm{bc}$ & $152.2 \mathrm{bcd}$ & $135.2 \mathrm{a}$ \\
HB4 & $27.8 \mathrm{cdef}$ & $122.0 \mathrm{de}$ & $99.2 \mathrm{bcd}$ \\
HB5 & $12.2 \mathrm{gh}$ & $55.8 \mathrm{gh}$ & $28.5 \mathrm{f}$ \\
HB6 & $166.8 \mathrm{bc}$ & $121.0 \mathrm{ab}$ \\
HB7 & $59.2 \mathrm{a}$ & $56.0 \mathrm{gh}$ & $87.7 \mathrm{~cd}$ \\
HB8 & $13.8 \mathrm{fgh}$ & $19.8 \mathrm{fgh}$ & $51.5 \mathrm{ef}$ \\
HB9 & $20.5 \mathrm{cdefgh}$ & $177.7 \mathrm{ab}$ & $106.5 \mathrm{abc}$ \\
HB10 & $43.2 \mathrm{ab}$ & $115.2 \mathrm{def}$ & $80.0 \mathrm{cde}$ \\
HB11 & $48.8 \mathrm{~h}$ & $29.0 \mathrm{f}$ \\
HB12 & $121.8 \mathrm{de}$ & $76.2 \mathrm{de}$ \\
HB13 & $10.5 \mathrm{~h}$ & $72.2 \mathrm{gh}$ & $52.2 \mathrm{ef}$ \\
HB14 & $30.2 \mathrm{bcd}$ & $91.0 \mathrm{efg}$ & $52.5 \mathrm{ef}$ \\
HB15 & $16.8 \mathrm{defgh}$ & $135.0 \mathrm{~cd}$ & $77.2 \mathrm{cde}$ \\
\hline CV $(\%)$ & $21.8 \mathrm{cdefgh}$ & 13.77 & 15.51 \\
\hline
\end{tabular}

Means followed by the same letter in the column are not different by the Tukey's test $(\mathrm{P}>0.05)$.

\section{DISCUSSION}

The $P$. gigantocarpa fruits presented superior biometric characteristics than other species of the same genus, such as P. nitida Miquel (CRUZ et al., 2001) and P. pendula (Willd.) Benth. ex Walp (CÂMARA et al., 2008). According to Silva et al. (2012), the comparative analysis of species of the genus Hymenaea showed that biometry parameters should be considered for differentiating species of the same genus. The species Hymenaea intermedia Ducke and $H$. martiana Hayne were easily differentiated from the others based on the biometric parameters related to fruits and seeds, respectively, which were more efficient to differentiate the species.

Variations in fruit dimensions can be attributed to genetic variability, biotic and abiotic environmental factors, and genotype-environment interaction (SANTANA et al., 2013). The coefficient of variation found $(20.3 \%)$ for fruit weight was higher than those for the other parameters related to fruits; however, this can be attributed to the different seed water contents during maturation, differences in time of fruit collection, and different climatic conditions of the sampling location.

The variations found in fruits and seeds of $P$. gigantocarpa were also found for other native species, such as Bertholletia excelsa Bonpl. (ROCHA et al., 2016). According to Araújo et al. (2015), native species have high variability in morphological characteristics of fruits and seeds, and it can be explained by the high genetic diversity of these plants.

The effect of the environment on seed development is expressed mainly by variations in size, weight, physiological potential, and health, since the environment has strong influence on seed production, pollination efficiency, presence of pollination agents, conservation status of the forest, and climate conditions during maturation.

The $P$. gigantocarpa seed biometrics found was different than those found for $P$. pendula seeds (CÂMARA et al., 2008). Thus, the results make easy the identification of $P$. gigantocarpa species and differentiate it from other species of the same genus.

The seed distinction and classification by weight and size can be efficient to improve seed quality regarding emergence uniformity and seedling vigor. Large seeds have more reserve tissues and, consequently, they tend to emerge faster, forming seedlings of similar sizes and with better vigor (CARVALHO; NAKAGAWA, 2012), ensuring a high seed market value. 
The positive and significant correlations found show that the studied characteristics increased in the same direction, i.e., the higher the fruit weight and length, the higher the number of seeds per fruit and seed weight. Gusmão et al. (2006) also found positive correlation of fruit fresh weight and fruit length of murici (Byrsonima verbascifolia Rich. Ex A. Juss.) with fruit size.

The seed size and weight of some species can indicate their physiological quality: in a same batch, lighter seeds usually present lower performance in germination and initial growth than heavier ones due to the amount of reserves accumulated (BEZERRA et al., 2004). However, this does not apply to the treatment HB3 because the low seed water content and low seed weight apparently did not affect the seed physiological quality of plants in this treatment, which presented high emergence (98\%) and emergence speed index (3.8).

The emergence speed index found for the treatments HB3 and HB9 showed that their seeds were more vigorous than those of the others treatments. According to Nakagawa (1999), the higher this index, the vigorous the seed batch or sample.

The results of the germination test presented high variations. According to Silva et al. (2014), these variations can be due to several factors, such as those related to the genetic variability of the parent plants and environmental effects during the seed development. The genetic variability of the parent plants evaluated can be connected to their crossed reproduction system, or because this is a non-domesticated species. The superiority of a parent plant can be verified by progeny tests.

Seedlings from the parent plants HB2, HB3, HB6, and HB9 had higher dry weight. According to Amaro et al. (2015), more vigorous seeds result in seedlings with higher growth rates and weight gain by present higher capacity to form tissues and supply accumulated reserves, thus, this characteristic is efficient for evaluations of seed vigor. The authors reported that results of dry weight tests can be obtained from seedlings used for emergence test, which is a viable option for seed physiological quality evaluation because it has a low cost, does not require special equipment or specific training, and is relatively fast (Amaro et al., 2015)

The similar results found for biometry characteristics of fruits and seeds and the evaluation of seed germination and seedling vigor indicated existence of variability (genetic, environmental, or genotypeenvironment interaction) among the parent plants of $P$. gigantocarpa evaluated in the present work. Information on biometry variations in size and weight of fruits and seeds and their correlation can subsidize the selection of superior parent plants for germination and seedling initial development; this indicates the importance of studies with seeds from different parents to provide information for further ecological and silvicultural studies on this species.

\section{CONCLUSIONS}

- Seeds from different parent plants of Parkia gigantocarpa present high variability in biometry characteristics of fruits and seeds, but allow the differentiation of the species from other species of the same genus.

- Seeds from different parent plants of $P$. gigantocarpa present different germination capacity and seedling vigor.

\section{REFERENCES}

AMARO, H. T. R. et al . Testes de vigor para avaliação da qualidade fisiológica de sementes de feijoeiro. Rev. de Ciências Agrárias, Lisboa, v.38, n. 3, p. 383-389, set. 2015. Disponível em <http://www.scielo.mec.pt/scielo.php?script=sci_arttext\&pid=S0871-018X2015000300013\&lng=pt\&nrm=iso>. acessos em 20 nov. 2017.

ARAÚJO, B. A.; SILVA, M. C. B.; MOREIRA, F. J. C.; SILVA, K. F.; TAVARES, M. K. N. Caracterização biométrica de frutos e sementes, química e rendimento de polpa de juazeiro (Ziziphus joaseiro Mart.). Agropecuária Científica no Semi-Árido, v. 11, n. 2, p. 15-21, 2015. Disponível em: http://revistas.ufcg.edu.br/acsa/index.php/ACSA/article/view/605/pdf. Acesso em: 30 nov. 2017.

BEZERRA, A. M. E.; MOMENTÉ, V. G.; MEDEIROS FILHO, S. Germinação de sementes e desenvolvimento de plântulas de moringa (Moringa oleifera Lam.) em função do peso da semente e do tipo de substrato. Horticultura Brasileira. Brasília. v. 22, n.2, p.295-299, 2004. Disponível em: http://dx.doi.org/10.1590/S010205362004000200026 . Acesso em: agosto de 2017.

BRASIL. Ministério da Agricultura e Reforma Agrária. Regras para análise de sementes. Brasília: SNAD/DNDV/CLAV, 2009. 399 p.

FLORESTA, Curitiba, PR, v. 50, n. 1, p. 877 - 886, jan/mar 2020.

Barros, H. S. D. et.al.

ISSN eletrônico 1982-4688

DOI: $10.5380 /$ rf.v50 i1.56855 
CÂMARA, C. A.; ARAÚJO NETO, J. C.; FERREIRA, V. M.; ALVES, E. U.; MOURA, F. B. P. Caracterização morfométrica de frutos e sementes e efeito da temperatura na germinação de Parkia pendula (Willd.) Benth. ex Walp. Ciência Florestal, Santa Maria, v. 18, n. 3, p. 281-290, 2008.

CARVALHO, N. M.; NAKAGAWA, J. Sementes: ciência, tecnologia e produção. 5. ed. Jaboticabal: FUNEP, 2012. $590 \mathrm{p}$.

CARVALHO, P. E. R. Espécies arbóreas brasileiras. Brasília: Embrapa Informação Tecnológica; Colombo: Embrapa Florestas, 2010. 644 p. (Coleção Espécies Arbóreas Brasileiras, 4).

CROMARTY, A. S.; ELLIS, R. H.; ROBERTS, E. H. Design of seed storage facilities for genetic conservation. Rome: International Board of Plant Genetic Resources, 1985. 100 p.

CRUZ, E. D.; CARVALHO, J. E. U.; LEÃO, N. V. M. Métodos para superação da dormência e biometria de frutos e sementes de Parkia nitida Miquel. (Leguminosae-Mimosoideae). Acta Amazônica, Manaus, v. 31, n. 2, p. 167-177, 2001.

EMBRAPA Amazônia Oriental. Fava-atanã: Parkia gigantocarpa. Belém: EMPRAPA Amazônia Oriental, 2004. 60 p. (Espécies arbóreas da Amazônia, v. 1, n.11). Folder.

FONTENELLE, A. C. F.; ARAGÃO, W. M.; RANGEL, J. H. A. A biometria de frutos e sementes de Desmanthus virgatus (L) Willd Nativas de Sergipe. Revista Brasileira de Biociências, Porto Alegre, (Nota Cientifica) v.5, n.1, p.252-254, 2007.

GOMES, J. M.; CARVALHO, J. O. P.; SILVA, M. G.; NOBRE, D. N. V.; TAFFAREL, M.; FERREIRA, J. E. R.; SANTOS, R. N. J. Sobrevivência de espécies arbóreas plantadas em clareiras causadas pela colheita de madeira em uma floresta de terra firme no município de Paragominas na Amazônia brasileira. Acta Amazônica, Manaus, v. 40 , n. 1 , p. $171-178,2010$.

GUSMÃO, E.; VIEIRA F. A.; FONSECA JUNIOR, E. M. F. Biometria de frutos e endocarpos de murici (Byrsonima verbascifolia Rich. ex A. Juss.). Cerne, Lavras, v. 12, n. 1, p. 84 - 91, 2006.

MAGUIRE, J. D. Speed of germination-aid in selection and evaluation for seedlig emergence and vigor. Crop Science, Madison, v. 2, n. 1, p. 176-177, 1962.

NAKAGAWA, J. Testes de vigor baseados no desempenho das plântulas. In: KRZYZANOWSKI, F. C.; VIEIRA, R. D.; FRANÇA NETO, J. B. (Eds.). Vigor de sementes: conceitos e testes. Londrina: ABRATES, 1999. p. 2.1 2.24 .

PAULA, J. E.; ALVES, J. L. H. Madeiras nativas: anatomia, dendrologia, dendrometria, produção e uso. Brasília: Fundação Mokiti Okada, 1997. 543 p.

ROCHA, V. D.; LIMA, J. S.; BISPO, R. B.; COCHEV, J. S.; ROSSI, A. A. B. Caracterização biométrica de frutos e sementes de Castanha-do-Brasil na Amazônia Mato-Grossense. Enciclopédia Biosfera, v. 13, n. 29, p. 185-195, 2016. Disponível em: www.conhecer.org.br/enciclop/2016b/agrarias/caracterizacao\%20biometrica Acesso em: 16 out. 2017.

SANTANA, S.H.; TORRES, S.B.; BENEDITO, C.P.. Biometria de frutos e sementes e germinação de melão-desão-caetano. Rev. Bras. Plantas Med., Botucatu , v. 15, n. 2, p. 169-175, 2013.

SILVA, G. R. C.; RODRIGUES, C. M.; MIRANDA, S. C. Dados biométricos de frutos e sementes de Hymenaea courbaril var. stilbocarpa (Hayne) YT Lee \& Langenh e H. martiana Hayne. Biotemas, Florianópolis, v. 25, n. 3, p. 121-127, 2012.

SILVA, K. B. et al. Variabilidade da germinação e caracteres de frutos e sementes entre matrizes de Sideroxylon obtusifolium (Roem. \& Schult.) TD Penn. Revista Eletrônica de Biologia, v. 7, n. 3, p. 281-300, 2014.

SILVA, B. M. S.; MÔRO, F. V. Aspectos morfológicos do fruto, da semente e desenvolvimento pós-seminal de faveira (Clitoria fairchildiana R. A. Howard.-Fabaceae). Revista Brasileira de Sementes, Londrina, v.30, n.3, 2008.

ZAR, J. H. Biostatistical Analysis. New Jersey: Prentice-Hall, 4 ed. 1999. 662 p. 